\title{
Black beetle: lessons from the past and options for the future
}

\author{
N.L. BELL ${ }^{1}$, R.J. TOWNSEND ${ }^{2}$, A.J. POPAY ${ }^{1}$, C.F. MERCER ${ }^{3}$, and T.A. JACKSON ${ }^{2}$ \\ ${ }^{1}$ AgResearch, Ruakura Research Centre, Private Bag 3123, Hamilton \\ ${ }^{2}$ AgResearch, Canterbury Science Centre, Lincoln \\ ${ }^{3}$ AgResearch, Private Bag 11008, Palmerston North \\ nigel.bell@agresearch.co.nz
}

\begin{abstract}
An outbreak of the pasture insect pest black beetle began in the Waikato and Bay of Plenty in 2007/8 and has persisted. The extent and severity of damage caused by black beetle during the current outbreak has focused farmer and researcher attention on methods to maintain persistent pasture now and in future outbreaks. This paper reviews previous research in combination with data from the current outbreak and relates these to current pasture management practice. The possibility of being able to predict the distribution, occurrence and duration of black beetle outbreaks is explored while actual and potential means of controlling black beetle are outlined. We conclude that there are methods available to successfully renew pastures in the presence of black beetle but that outbreak situations increase risks and may limit subsequent pasture persistence. There are fewer readily available options to maintain an existing pasture and more research is urgently needed to provide these options.
\end{abstract}

Keywords: Heteronychus arator, paspalum, pasture, pasture renewal, pest resistance, pest tolerance, ryegrass

\section{Introduction}

Black beetle (Heteronychus arator (Fabricius)) was first observed in New Zealand in the late 1930s (Todd 1959) and has since become an established pest in the northern part of the country. This review aims to give background to black beetle research that has been conducted in New Zealand, to identify gaps in knowledge which would assist in management of this pest and to give some indications of the control methods currently available to land managers in new and existing pastures.

\section{Distribution - worldwide and entry to New Zealand} Black beetle was originally described from the Cape of Good Hope, South Africa as Scarabaeus arator (Fabricius 1775). It is now known to be distributed throughout southern and eastern Africa (Ethiopia to South Africa) and has spread to South America, Australia (New South Wales, Queensland, South Australia, Western Australia and Norfolk Island) and New Zealand (CAB International 2000).

In New Zealand, black beetle is confined to the upper
North Island, with an earlier report of an occurrence in Canterbury (Brown 1964) presumably a mistaken identity. Beetles were first reported from areas around Auckland in the late 1930s and by the late 1950s had been observed as far north as Dargaville with its southern continuous extent being from the base of the Awhitu Peninsula to the base of the Coromandel Peninsula with pockets of infestation reported around the Gisborne area (Todd 1959). By the early 1970s the continuous distribution extended to the northern-most tip of the North Island and southwards to Raglan on the west coast and across to Tauranga in the east, including a coastal strip to near the tip of East Cape (Esson 1973). The occurrence in the Gisborne area was, by then, confirmed (Esson 1973). Watson (1979) considered the distribution of black beetle to be confined to areas with a mean annual soil surface temperature of $12.8^{\circ} \mathrm{C}$ which, based on current National Institute of Water and Atmospheric Research Virtual Climate Station (VCS) data (Tait \& Woods 2007), would include a continuous coastal strip around East Cape and down to Cape Kidnappers in the east with a southerly distribution including a strip of the west coast to about Whanganui (Fig. 1). This indicates that the range has gradually extended south over the last 30-40 years, incorporating southern parts of Waikato and Bay of Plenty and parts of inland Hawkes Bay. This places new areas at risk of significant damage during outbreaks.

\section{Lifecycle and flight behaviour}

The black beetle has a single generation per year (Fig. 2). In warmer areas of the country, spring development may be much quicker than shown in Fig. 2 with firststage larvae being observed in early October in sandy soil near Dargaville (Esson 1973). Feeding on grass roots close to the soil surface by the third-stage larvae from mid-January to March causes severe damage at a time when plants are already under moisture and temperature stress and inevitably kills plants.

Adult beetles can fly and large massed flights can be observed in the autumn of outbreak years, with Watson (1979) trapping $>85,000$ beetles in massed flights in March 1975. Much smaller flights normally occur in spring from late September to December, but these are also massed such that most flights occur on few 
( $\leq$ four) evenings per season (Watson 1979). During outbreak years, spring flights may be considerably larger than normal (P.D. King quoted in Watson 1979). Initial autumn flights appear to be triggered by the first significant rainfall after adults emerge from pupae, with these and subsequent flights occurring when soil surface temperatures exceed about $17^{\circ} \mathrm{C}$ at dusk with calm wind conditions (Watson 1979). Densitydependent spring flight migrations prior to oviposition may also occur (King et al. 1981d). Dispersal of the beetles during autumn and spring potentially plays a crucial role in infesting new pastures during outbreak years. Further research is needed to increase our understanding of this, particularly as it relates to the use of endophyte and insecticidal seed coatings to reduce black beetle infestations.

\section{Hosts}

Grasses, including paspalum (Paspalum dilatatum) and ryegrasses (Lolium spp.), are the preferred hosts of both larval and adult black beetle (King 1976; King et al. 1981c; King et al. 1981e; King et al. 1981f; King et al. 1981g; Todd 1959) and these also act as preferred oviposition sites (King et al. 1981b). Although black beetle larvae will consume white clover (Trifolium repens) when given no choice (King et al. 1981g), it appears that legumes are generally unfavourable hosts (King et al. 1981a; Sutherland \& Greenfield 1978). Carrots are suitable food for larvae and adults in the laboratory (King, 1981c; pers obs). It appears that soil organic matter may act as a feeding stimulant for larval black beetle (King 1977), which may have implications for the amount of plant damage incurred in peat soils.

By sowing a non-host crop in spring such as brassicas, legumes or chicory it may be possible to disrupt larval feeding over summer thus breaking the black beetle lifecycle and helping to ensure a low population density is present once pastures are resown in autumn. A cropping phase would also allow for control of weedy host grasses such as paspalum and annual poa (Poа апnиа).

\section{Sampling methods for on-farm monitoring}

To make timely treatment decisions or to adjust farm management strategies which compensate for pasture production losses, farmers need a way to predict potential future black beetle populations. Watson et al. (1980a) showed that it is possible to determine whether individual paddocks were at risk of developing damaging summer populations of black beetle larvae by monitoring black beetle adults during the preceding spring. The monitoring system advocated required approximately half a person-hour per paddock to assess beetle numbers from nine representative samples, 20- cm square spade divots approx. 8-cm deep, across each paddock. If the average number of beetles found in the paddock was above $10 / \mathrm{m}^{2}$ the pasture was considered to be at risk of suffering significant damage the following summer. A damaging larval population was defined as 40-60 larvae/ $\mathrm{m}^{2}$ dependent on a range of abiotic and biotic factors such as soil moisture, soil temperature and host availability (King 1979; King et al. 1982). Using pitfall traps to estimate black beetle populations in spring pasture was an unreliable method of assessing beetle density (King et al. 1980).

\section{Population levels and modelling}

Populations of black beetle undergo periodic outbreaks during which severe pasture damage occurs. Population modelling work conducted in the early 1980s (King et al. 1981d) attempted to understand what drove outbreaks and thereby allow prediction of them. That work was largely carried out in paspalum-dominated pastures which were common at that time and produced more stable beetle populations than the ryegrass pastures with which they were compared (King et al. 1981f). The ryegrass cultivars used (e.g., Grasslands Ruanui (King et al. 1981e)) would most likely have contained standard endophyte (see Endophyte section for explanation of endophyte strains). Therefore, the decline in beetle populations they observed from February to September in ryegrass plots, leading to the conclusion that ryegrass pastures were suitable habitats only over the spring and summer periods (King et al. 1981f), may well have been an effect of the endophyte status of the plants rather than their suitability as a food source per se.

From the models developed in the 1980s in paspalum, the critical factors to black beetle population increase were: thermal units above $15^{\circ} \mathrm{C}$ between 1 September and 30 November; and density-dependent variation in natality (King et al. 1981d). The thermal units calculation for September-November seems to fit both paspalum and ryegrass data (King et al. 1981d) but some of the other key factors in the beetle life cycle were thought to be more important beneath ryegrass than paspalum. High soil moistures, for instance, appear to be unfavourable for young larvae (King 1979). King et al. (1981d) noted that their model was preliminary and needed to be tested with data added from a broader range of pasture types. Additionally they noted that adult flight dispersal needed to be investigated and the impact this may have on population dynamics incorporated into the model. It is unclear, therefore, how well the population models developed previously fit with the current situation and across a wider geographical range.

Although climatic factors are obviously an important determinant in black beetle population changes, the 
Figure 1 Current expected distribution of black beetle based on the $12.8^{\circ} \mathrm{C}$ mean annual air temperature isotherm (NIWA 1971-2000). Note small pockets of coast as far south as Wellington where the $12.8^{\circ} \mathrm{C}$ isotherm is met or exceeded.

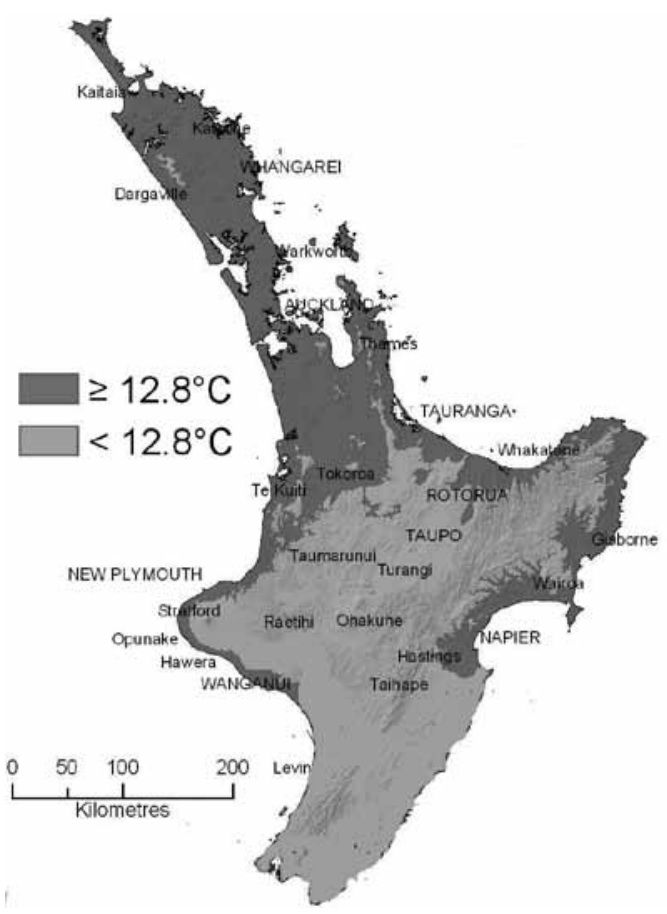

role of food resources for overwintering adult beetles is also a critical factor. A large decline in adult black beetle populations between autumn and spring observed by King et al. (1981f) may have been caused by the presence of standard endophyte deterring adult feeding. Not only does this affect beetle survival but it also reduces the numbers of eggs laid in spring by the surviving beetles (Popay \& Baltus 2001). Thus it is likely that the increased use of annual ryegrasses (commercial lines don't have endophyte) in pasture to boost winter and spring production would also increase survival of beetles over winter. Additionally, use of perennial ryegrasses with endophytes that do not deter black beetle would likely lead to greater black beetle feeding and therefore survival. The occurrence of paspalum in pastures has, at least anecdotally, declined in the last decade (a decline in paspalum abundance in Northland was noted as early as the 1970s (Percival 1977)) which has potentially removed a reservoir for beetles from which to establish new populations. This may be offset by the recent expansion of kikuyu (Pennistum clandestinum), another favourable host (Blank \& Olson 1988), previously limited to Northland (Percival 1978), into the Bay of Plenty and Waikato. There are also other $\mathrm{C}_{4}$ grasses in intensive dairy grazed pastures, present in greater abundance than paspalum
Figure 2 Lifecycle of black beetle showing relative sizes of life stages. Beetle larvae reach ca. $2.5 \mathrm{~cm}$ length in February.

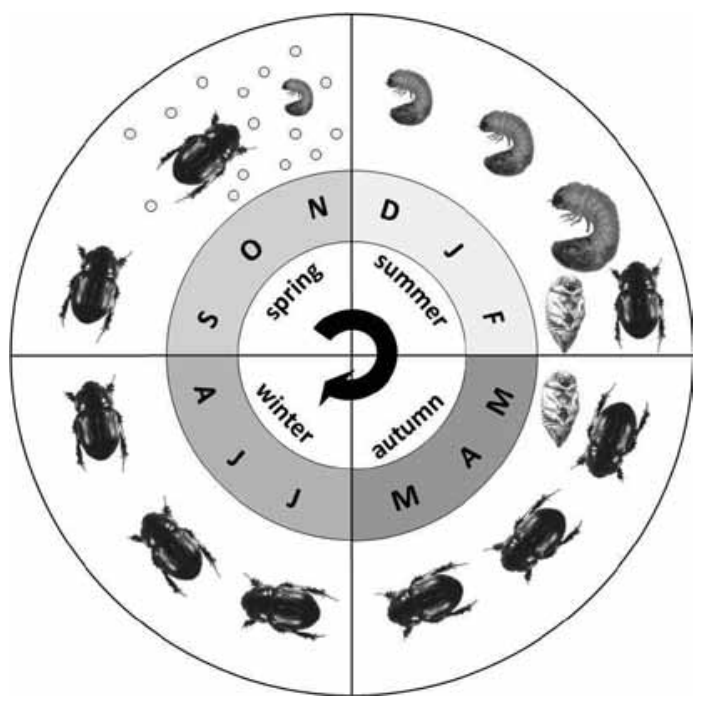

(Tozer et al. 2008), which can act as hosts for black beetle. Future modelling to enable better prediction of population outbreaks should also take into account the effect of favourable food resources.

\section{Pasture production effects/damage threshold}

In an experiment carried out in plastic tubs, Watson \& Marsden (1982) found that adult black beetle reduced ryegrass yields over the winter/spring period by $59 \%$ with populations as low as $20 / \mathrm{m}^{2}$ and that at high populations $\left(160 / \mathrm{m}^{2}\right)$, ryegrass yielded $97 \%$ less than controls. Paspalum was able to withstand much greater beetle populations than ryegrass with $28 \%$ yield reduction at $80 / \mathrm{m}^{2}$ and plants able to recover from damage at all but the $160 / \mathrm{m}^{2}$ rate (Watson \& Marsden 1982). In the field the adults are generally not considered to be particularly damaging to established ryegrass pastures. They can, however, considerably reduce seedling numbers in newly sown pastures.

The root feeding larvae are the most damaging stage. In field plots in sandy clay soil at Otakanini, near Helensville, King et al. (1982) measured a decline of the ryegrass component in pure ryegrass plots $(36 \%)$ and in mixed ryegrass/white clover plots $(67 \%)$ when the population of black beetles were $40-60 / \mathrm{m}^{2}$ in February. From this and other work (Watson et al. 1980a) it appears the number of beetles (particularly larvae) needed to cause substantial damage to pastures can be as low as $20 / \mathrm{m}^{2}$ or as high as $40 / \mathrm{m}^{2}$.

\section{Endophyte}

Endophytes are fungal symbionts which occur naturally in some grasses (standard endophyte) and strains have 
been selected which produce insect deterrent alkaloids but do not produce alkaloids toxic to grazing mammals that occur in standard endophyte. Some endophyte strains reduce adult feeding (Ball et al. 1994) which in turn reduces beetle survival and oviposition. However, no commercially available strain has shown deleterious effects on larvae. Ergovaline, which is also a mammalian toxin, has been identified as the alkaloid produced by the standard endophyte which deters the adult beetle. The AR1 endophyte strain, which does not produce ergovaline, is not a strong deterrent to the adult, although it does reduce adult feeding relative to endophyte-free ryegrass (Popay \& Baltus 2001). Certainly in the field AR1-infected ryegrass is considerably more vulnerable to damage by black beetle larvae compared with ryegrass infected with the standard endophyte (Hume et al. 2007; Popay \& Baltus 2001; Popay \& Thom 2009). Two endophytes available in tetraploid ryegrasses, NEA2 and Endo 5, produce low levels of ergovaline which is sufficient to reduce black beetle populations. Another endophyte which does not produce ergovaline, AR37, does however, have a strong effect on adult black beetle (Ball et al. 1994) and in the field reduces black beetle populations to the same extent as the standard endophyte (Hume et al. 2007; Thom et al. 2008)

During black beetle outbreaks, the adult deterrence conferred by even the best selected endophytes may be insufficient to prevent damaging populations of larvae from building up or new infestations arising as a result of massed adult beetle migration in late autumn or spring. Pastures opened up to invasion by $\mathrm{C}_{4}$ grasses or Pоа апnиа, which are alternative hosts for adult beetles, can allow populations to increase in an otherwise resistant sward.

\section{Insecticide control}

A range of insecticides have been investigated for their use in controlling black beetle in pastures and crops. Many of these have either been taken off the market or are no longer registered for black beetle control and none are currently recommended for black beetle control in established pastures. From a number of trials in pasture (Blank \& Olson 1988; King et al. 1982; Watson et al. 1978; Watson \& Webber 1975, 1976; Watson et al. 1980c) and crops (Watson et al. 1980b) the best beetle control seems to be achieved when insecticides are used against the early summer (December) populations of beetles. Modelling work also suggests that control directed against the early larval stages in December will have a greater impact on the damaging summer population of beetles than controls applied in early spring, before eggs are laid (East et al. 1981). Research is presently being conducted in pastures on "off label" uses of currently available insecticides for spring and early summer control of beetles. In the past, a range of soil types have been used when testing insecticides and some particular application techniques may be required when dealing with soil with high organic matter content (King \& Mercer 1974).

Pasture renewal is one phase of the pasture persistence cycle where insecticides are readily available for use, in the form of seed coats (Anonymous 2009). This is likely to be a useful way to reduce adult black beetle numbers in autumn-sown pasture thereby reducing the number of beetles overwintering which then give rise to the next spring's population. Use of insecticidal seed coatings is likely to be critical to pasture establishment in outbreak years but could also be useful for reducing the risk of populations building up after pasture renewal carried out in years between outbreaks.

\section{Biocontrol}

Pathogens of black beetle that have been identified include the protozoa Adelina, Beauveria fungus, a ricketsia and an RNA virus (Archibald et al. 1975; King et al. 1985; Longworth \& Archibald 1975). Work in New Zealand (Longworth \& Archibald 1975) and in Australia (Ford et al. 2001) has suggested entomopathogenic nematodes may be useful control options that require further investigation.

\section{Current situation}

An outbreak of black beetle began in 2007/8 in the Waikato and Bay of Plenty areas and large population densities (up to 80 larvae $/ \mathrm{m}^{2}$ ) were still being measured in February 2010 (Bell, unpub. data). Damage has been severe and exacerbated by drought, with dramatic consequences on pasture persistence. Many questions have arisen from this outbreak. Could farmers have managed the outbreak better if it had been predicted? What management techniques could have been instigated to reduce the impact of the outbreak? Has the widespread planting of AR1 in the Waikato and Bay of Plenty contributed to the current outbreak? What are the best means of renovating pasture successfully during an outbreak so that it is less vulnerable to immediate invasion by this pest?

Methods for controlling black beetle, in addition to using the best endophytes, are certainly needed during outbreaks. Combining sowing of a non-host break crop with insecticidal seed coating and the correct endophytes will certainly help but other technologies are needed. Ideally we need to be able to predict when an outbreak is likely to occur and how sustained it is going to be so as to forewarn farmers and provide them with the advice they need to manage that situation. 


\section{ACKNOWLEDGEMENTS}

We are grateful to NIWA for provision of the original isotherm map. We thank Joanne Jensen and Trevor James for their helpful comments on an earlier version of the manuscript allowing it to go forward to publication.

\section{REFERENCES}

Anonymous 2009. New Zealand Novachem Agrichemical Manual. Agri Media Ltd, Christchurch, New Zealand. $135 \mathrm{pp}$.

Archibald, R.D.; Longworth, J.F.; King, P.D.; Mercer, C.F. 1975. The effect of two pathogens on a black beetle population in Kikuyu pasture. pp. 200-204. In: Proceedings of the 28th New Zealand Weed and Pest Control Conference.

Ball, O.J.-P.; Christensen, M.J.; Prestidge, R.A.; Popay, A.J. 1994. Effect of selected isolates of Acremonium endophyte on adult black beetle (Heteronychus arator) feeding. pp. 227-231. In: Proceedings of the 47th New Zealand Plant Protection Conference.

Blank, R.H.; Olson, M.H. 1988. Effect of black beetle, in association with nitrogen and summer spelling, on pasture production on sandy soils. New Zealand Journal of Agricultural Research 31: 445-453.

Brown, J.G. 1964. Occurrance of black beetle Heteronychus sanctae-helenae Blanch (Dynastidae, Col.) in Canterbury. New Zealand Journal of Agricultural Research 7: 434.

CAB International 2000. Heteronychus arator. Distribution Maps of Plant Pests. pp. Map 163. In: Distribution Maps of Plant Pests. Eds. CAB International, Wallingford.

East, R.; King, P.D.; Watson, R.N. 1981. Population studies of grass grub (Costelytra zealandica) and black beetle (Heteronychus arator) (Coleoptera: Scarabaeidae). New Zealand Journal of Ecology 4: 56-64.

Esson, M.J. 1973. Biology and distribution of black beetle (Heteronychus arator). pp. 184-188. In: Proceedings of the 26th New Zealand Weed and Pest Control Conference.

Fabricius, J.C. 1775. Systema Entomologiae, sistens Insectorum Classes, Ordines, Genera, Species, adiectis Synonymis, Locis, Descriptionibus, Observationibus. Flensburgi \& Lipsiae : Officina Libraria Kortii. 832 pp.

Ford, P.; Olszewski, I.; Nickson, D. 2001. Biological control of African black beetle (Heteronychus arator) in turf using entomopathogenic nematodes. Victorian Golf Association Turf Research and Advisory Board, $7 \mathrm{pp}$.

Hume, D.E.; Ryan, D.L.; Cooper, B.M.; Popay, A.J. 2007. Agronomic performance of AR37-infected ryegrass in northern New Zealand. Proceedings of the New Zealand Grassland Association 69: 201-205.

King, P.D. 1976. The effect of pasture species on black beetle. pp. 161-164. In: Proceedings of the 29th New Zealand Weed and Pest Control Conference.

King, P.D. 1977. Effect of plant species and organic matter on feeding behaviour and weight gain of larval black beetle, Heteronychus arator (Coleoptera: Scarabaeidae). New Zealand Journal of Zoology 4: 445-448.

King, P.D. 1979. Aspects of the ecology of black beetle, Heteronychus arator (F.). Unpublished D. Phil. thesis. University of Waikato, Hamilton.

King, P.D.; Meekings, J.S.; Mercer, C.F. 1982. Effects of whitefringed weevil (Graphognathus leucoloma) and black beetle (Heteronychus arator) populations on pasture species. New Zealand Journal of Agricultural Research 25: 405-414.

King, P.D.; Meekings, J.S.; Phillip, K.C. 1985. A protozoan pathogen of black beetle. pp. 201-209. In: Proceedings of the 4th Australasian Conference on Grassland Invertebrate Ecology.

King, P.D.; Meekings, J.S.; Smith, S.M. 1980. An evaluation of pitfall trapping as a method of estimating black beetle populations in spring. pp. 148-150. In: Proceedings of the 33rd New Zealand Weed and Pest Control Conference.

King, P.D.; Mercer, C.F. 1974. Insecticidal control of black beetle on a peat soil type. pp. 228-229. In: Proceedings of the 27th New Zealand Weed and Pest Control Conference.

King, P.D.; Mercer, C.F.; Meekings, J.S. 1981a. Ecology of black beetle Heteronychus arator. Influence of plant species on larval consumption, utilization and growth. Entomologia Experimentalis Et Applicata 29: 109-116.

King, P.D.; Mercer, C.F.; Meekings, J.S. 1981b. Ecology of black beetle, Heteronychus arator (Coleoptera: Scarabaeidae) - influence of pasture species on oviposition site preference. New Zealand Journal of Zoology 8: 119-122.

King, P.D.; Mercer, C.F.; Meekings, J.S. 1981c. Ecology of black beetle, Heteronychus arator (Coleoptera: Scarabaeidae) - influence of temperature on feeding, growth, and survival of the larvae. New Zealand Journal of Zoology 8: 113-117.

King, P.D.; Mercer, C.F.; Meekings, J.S. 1981d. Ecology of black beetle, Heteronychus arator (Coleoptera: Scarabaeidae) - population modelling. New Zealand Journal of Agricultural Research 24: 99-105.

King, P.D.; Mercer, C.F.; Meekings, J.S. 1981e. Ecology of black beetle, Heteronychus arator (Coleoptera: Scarabaeidae) - population sampling. New Zealand Journal of Agricultural Research 24: 79-86.

King, P.D.; Mercer, C.F.; Meekings, J.S. 1981f. Ecology 
of black beetle, Heteronychus arator (Coleoptera: Scarabaeidae) - population studies. New Zealand Journal of Agricultural Research 24: 87-97.

King, P.D.; Mercer, C.F.; Meekings, J.S. 1981g. Ecology of black beetle, Heteronychus arator (Coleoptera: Scarabaeidae) - relative consumption of pasture plant roots by larvae. New Zealand Journal of Zoology 8: 123-125.

Longworth, J.F.; Archibald, R.D. 1975. A virus of black beetle, Heteronychus arator (F.) (Coleoptera: Scarabaeidae). New Zealand Journal of Zoology 2: 233-236.

Percival, N.S. 1977. Survey of paspalum in New Zealand pastures. New Zealand Journal of Experimental Agriculture 5: 219-226.

Percival, N.S. 1978. Survey of kikuyu grass (Pennisetum clandestinum Hochst.) in New Zealand pastures. New Zealand Journal of Experimental Agriculture 6: 19-21.

Popay, A.J.; Baltus, J.G. 2001. Black beetle damage to perennial ryegrass infected with AR1 endophyte. Proceedings of the New Zealand Grassland Association 63: 267-271.

Popay, A.J.; Thom, E.R. 2009. Endophyte effects on major insect pests in Waikato dairy pasture. Proceedings of the New Zealand Grassland Association 71: 121-126.

Sutherland, O.R.W.; Greenfield, W.J. 1978. Effect of root extracts of resistant pasture plants on the feeding and survival of black beetle larvae. New Zealand Journal of Zoology 5: 173-175.

Tait, A.; Woods, R. 2007. Spatial interpolation of daily potential evapotranspiration for New Zealand using a spline model. Journal of Hydrometeorology 8: 430438.

Thom, E.R.; Waugh, C.D.; Minneé, E.M.K.; Waghorn, G.C.; Popay, A.J. 2008. Effects of novel ryegrass endophytes on pasture production and milk production from dairy cows in northern New Zealand. pp. 79. In: Multifunctional Grasslands in a Changing World, Vol II.

Todd, D.H. 1959. Black beetle Heteronychus sanctaehelenae Blanch., in pastures in New Zealand. New Zealand Journal of Agricultural Research 2: 12621273.
Tozer, K.N.; James, T.K.; Cameron, C.A. 2008. Botanical and management factors associated with Setaria pumila abundance: implications for pasture management. New Zealand Plant Protection 61: 121126.

Watson, R.N. 1979. Dispersal and distribution of Heteronychus arator in New Zealand (Coleoptera: Scarabaeidae). pp. 149-152. In: Proceedings of the 2nd Australasian Conference on Grassland Invertebrate Ecology.

Watson, R.N.; Holland, P.T.; Olson, M.H.; Hartley, M.J. 1978. Residual activity of two insecticides against black beetle. pp. 167-172. In: Proceedings of the 31st New Zealand Weed and Pest Control Conference.

Watson, R.N.; Marsden, R.S. 1982. Effects of adult black beetle (Coleoptera: Scarabaeidae) feeding on two grass species. pp. 107-115. In: Proceedings of the 3rd Australasian Conference on Grassland Invertebrate Ecology.

Watson, R.N.; Marsden, R.S.; Townsend, R.J. 1980a. Farm surveying of black beetle populations in spring as an indicator of larval populations in summer. pp. 144-147. In: Proceedings of the 33rd New Zealand Weed and Pest Control Conference.

Watson, R.N.; Marsden, R.S.; Townsend, R.J.; Hartley, M.J. 1980b. Post-emergent control of black beetle adults in field crops. pp. 206-210. In: Proceedings of the 33rd New Zealand Weed and Pest Control Conference.

Watson, R.N.; Webber, K. 1975. Insecticide screening trials against black beetle. pp. 264-267. In: Proceedings of the 28th New Zealand Weed and Pest Control Conference.

Watson, R.N.; Webber, K.J. 1976. Insecticide trials against black beetle in pasture. pp. 176-179. In: Proceedings of the 29th New Zealand Weed and Pest Control Conference.

Watson, R.N.; Wrenn, N.R.; Hartley, M.J. 1980c. An evaluation of the solid stream technique of insecticide application for control of black beetle in pasture. pp. 151-154. In: Proceedings of the 33rd New Zealand Weed and Pest Control Conference. 